\title{
Causes of Low Seed Quality in Ilex paraguariensis A. St. Hil. Samples (aquifoliaceae)
}

\author{
Anieli Cioato de Souza ${ }^{1}$ (D) 0000-0001-5989-5740 \\ Luciana Magda de Oliveira ${ }^{1}$ (I) 0000-0001-7362-1041 \\ Gabriela Fernanda Souza ${ }^{1}$ (1) 0000-0002-1875-9950 \\ Sharline Schossler Schmidt ${ }^{1}$ (D) 0000-0003-0606-5692 \\ Patrícia Paloma Liesch ${ }^{1}$ (1) 0000-0003-4880-8677
}

\begin{abstract}
This study sought to determine the possible causes of the low seed quality of $I$. paraguariensis A. St. Hil. Seeds from six samples collected at different sites were classified as empty, decayed, herbivorous and full. Viability was assessed by tetrazolium test in seeds filled with a visualized embryo. High amounts of empty and deteriorated seeds (54\% to 93\%) were verified in four of the evaluated samples, and insect attack was observed in two samples. The viability of visualized embryo-filled seeds was $83 \%$ to $100 \%$. Low quality generally results from the presence of empty and deteriorated seeds, as well as dormancy.
\end{abstract}

Keywords: empty seeds; herbivorous; yerba mate.

\section{INTRODUCTION AND OBJECTIVES}

Yerba mate (Ilex paraguariensis A. St. Hil.) plays an important socioeconomic role in the Southern region of brazil, where it is produced. The leaves are dried to prepare a traditional tea that is consumed by millions of people in South America (Oliveira \& Waquil, 2015).

Seedling production of the species is commonly performed by pyrenees (hereafter called "seeds"), which have around 5\% germinability (Cuquel et al., 1994). This low germinability may be associated with physiological deformations such as absence of embryo and deterioration, as well as herbivory. Therefore, the presence of insects and empty and deteriorated seeds has been observed in Ilex species such as I. latifolia (Takagi \& Togashi, 2013) and I. aquifolium (Arrieta \& Suarez, 2004; Garcia et al., 2005). Thus, this study sought to determine the possible causes of the low quality of I. paraguariensis seeds.

Six seed samples were obtained from at least five matrices with a minimum distance of five meters and a maximum of five hundred meters in native areas of different locations and/or years:
- OC-15: collected in 2015 in Otacílio Costa, SC. The average annual temperature is $16.3{ }^{\circ} \mathrm{C}$, with an average annual rainfall of $1,519 \mathrm{~mm}$ and $871 \mathrm{~m}$ altitude (Climate Data, 2014) (27 31' 41.82" S; $50^{\circ} 8$ ' 17.14" W - SIRGAS 2000).

- UR-15: collected in 2015 and UR-16: in 2016 in Urupema, SC. The average annual temperature is $14.1^{\circ} \mathrm{C}$, with an average annual rainfall of $1,634 \mathrm{~mm}$ and 1,324 m altitude (Climate Data, 2014) (27 57' 53.3' S; $49^{\circ} 50^{\prime} 20.3^{\prime \prime} \mathrm{W}$ - SIRGAS 2000).

- CE-16: collected in 2016, in Campo Erê, SC. The average annual temperature is $16.7^{\circ} \mathrm{C}$, with an average annual rainfall of 2,045 $\mathrm{mm}$ and $903 \mathrm{~m}$ altitude (Climate Data,

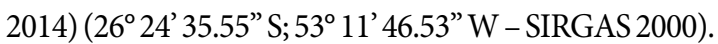

- IJ-16: collected in 2016 in Ijuí, RS. The average annual temperature is $19.9^{\circ} \mathrm{C}$, with an average annual rainfall of $1,774 \mathrm{~mm}$ and an altitude of $307 \mathrm{~m}$ (Climate Data,

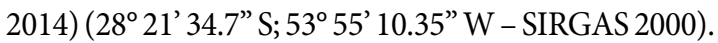

- PU-16: collected in 2016 in Porto União, SC. The average annual temperature is $17.7^{\circ} \mathrm{C}$, with an average annual rainfall of $1,667 \mathrm{~mm}$ and $780 \mathrm{~m}$ altitude (Climate Data,

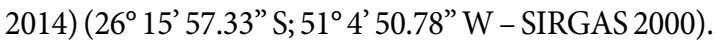

${ }^{1}$ Universidade do Estado de Santa Catarina (Udesc), Lages, SC, Brasil 
The fruits were ripe and with dark purple coloration 2.5/1 F: 5Y (Kollmorgen, 1975) (Figure 1). The seeds were extracted in a sieve and running water, dried on paper towels and used in the experiments.

Subsequently, 200 seeds, divided into four repetitions, were immersed in water for $24 \mathrm{~h}$ for each batch to facilitate longitudinal cutting. The seeds were evaluated visually with the aid of a Stemi- $305^{\circ}$ stereo microscope and classified into: Empty - without endosperm and embryo; Deteriorated with necrotic endosperm and embryo or coalescent tissues (Catapan, 1998); Filled with unseen embryo; Filled with visualized embryo; and Herbivorous - with the presence of insect or signs of herbivory (Figure 2).

For viability evaluation, seeds filled with a visualized embryo were immersed in $0.1 \%$ tetrazolium solution for $24 \mathrm{~h}$ at $35^{\circ} \mathrm{C}$ (Catapan, 1998).

The experiments were installed in a completely randomized design. Data were tested for normality by the Shapiro-Wilk test and homogeneity by the Bartlett's test, and analysis of variance was performed. Data with heterogeneous variance were transformed into arc sine $\sqrt{x} / 100$. Means were compared by the Tukey test at $5 \%$ probability. The Pearson's correlation was used to correlate environmental conditions and seed sample characterization.

The characteristics of I. paraguariensis seeds differed according to the sample; however, higher percentages of decayed and empty seeds were generally observed (Table 1).

The empty seeds (Figure 2a) were counted in greater number in the UR-16, UR-15, OC-16 and PU-16 samples with values between 27 and $44 \%$ (Table 1). These results may be related to pollination, distance between matrix trees, and the efficiency of natural pollinators (Ayub \& Mariath, 1996 apud Carvalho, 2003), since this is a dioecious species.

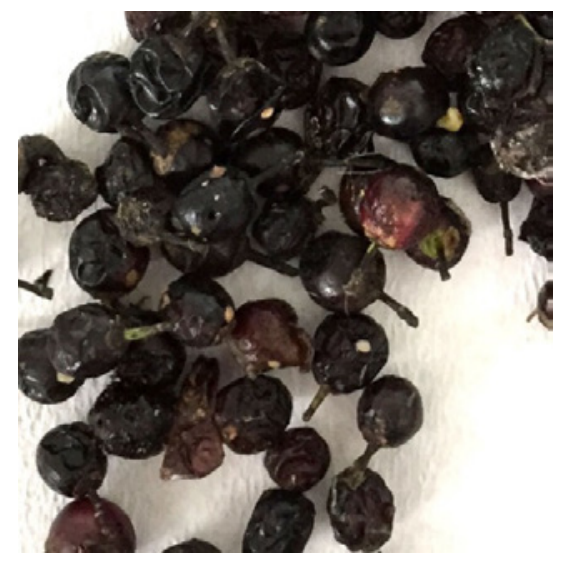

Figure 1. Mature Ilex paraguariensis fruit with a dark purple coloration -2.5/1 F: $5 Y$ (Kollmorgen, 1975). Scale bar: $10 \mathrm{~mm}$.

For the removal of empty seeds from a sample, Zanon (1988) suggests to immerse them in water and discard the supernatants. Sousa et al. (2003) observed that controlled pollination for $I$. paraguariensis is efficient and indicated for most of fruits and full seeds.

The PU-16 sample had the highest number of deteriorated seeds (Figure $2 \mathrm{~b}$ and Table 1 ), differing from the others. Although the presence of pathogens was not evaluated, Oliveira (2013) reports that seed deterioration may be fungi-related.

Regarding herbivory, micro-hymenopterans belonging to the family Torymidae were identified (Figure $2 \mathrm{c}$ ) by isolating the insect in OC-15 and UR-15 samples. These microwaps feed on the seed, and then exit through a hole that could be visually identified in the seeds (Figure 3).

In I. paraguariensis seeds from vintage 1982, provenances São Mateus do Sul-PR, Catanduvas-SC and Centenario-RS, Zanon (1988) verified the presence of unidentified micro hymenopteran, which caused approximately $50 \%$ of damaged seeds.
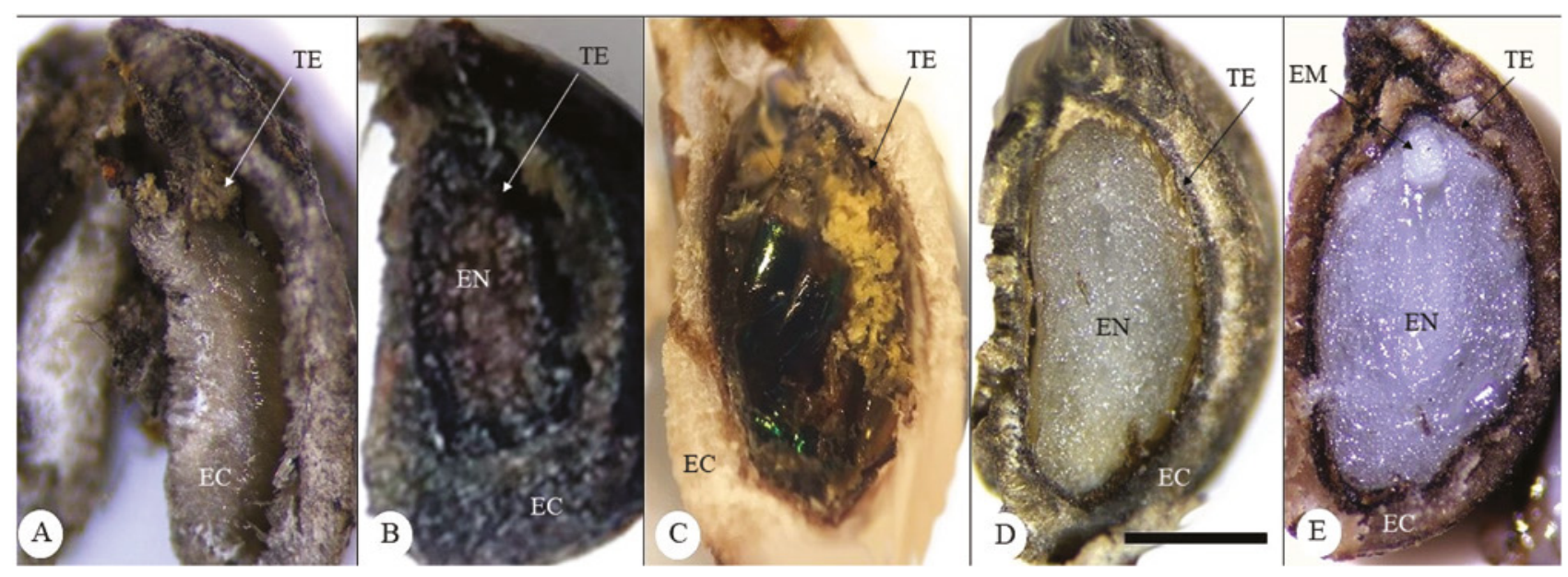

Figure 2. Ilex paraguariensis seeds classified as: empty (a); deteriorated (b); herbivorous (c); filled with unseen embryo (d); and filled with visualized embryo (e). Scale bar: $1 \mathrm{~mm}$.

EM: embryo; EN: endosperm; TE: coat; EC: endocarp. 
Table 1. Percentage of empty seeds (V), deteriorated (D), herbivorous (H), with visualized embryo (EV) and with unseen embryo (ENV), and viability (Viab) observed in samples of Ilex paraguariensis seeds.

\begin{tabular}{|c|c|c|c|c|c|c|}
\hline \multirow[b]{2}{*}{ SAMPLES } & \multirow[b]{2}{*}{$\mathbf{V}$} & \multirow[b]{2}{*}{ D } & \multirow[b]{2}{*}{$\mathbf{H}$} & \multicolumn{2}{|c|}{ Full } & \multirow[b]{2}{*}{ Viab } \\
\hline & & & & EV & ENV & \\
\hline OC-15 & $30.41 \mathrm{ab}$ & $24.37 \mathrm{c}$ & $0.99 \mathrm{a}$ & $6.22 \mathrm{~b}$ & $34.82 \mathrm{~b}$ & $100 \mathrm{a}$ \\
\hline UR-15 & $27.76 \mathrm{abc}$ & $42.23 \mathrm{ab}$ & $0.24 \mathrm{ab}$ & $28.62 \mathrm{a}$ & $0.70 \mathrm{c}$ & $100 \mathrm{a}$ \\
\hline UR-16 & $44.64 \mathrm{a}$ & $44.00 \mathrm{ab}$ & $0 \mathrm{~b}$ & $3.94 \mathrm{~b}$ & $7.42 \mathrm{c}$ & $88 \mathrm{c}$ \\
\hline CE-16 & $2.12 \mathrm{c}$ & $27.30 \mathrm{bc}$ & $0 \mathrm{~b}$ & $33.16 \mathrm{a}$ & $37.42 \mathrm{~b}$ & $83 \mathrm{~d}$ \\
\hline IJ-16 & $4.44 \mathrm{bc}$ & $3.53 \mathrm{~d}$ & $0 \mathrm{~b}$ & $26.50 \mathrm{a}$ & $65.53 \mathrm{a}$ & $96 \mathrm{~b}$ \\
\hline PU-16 & $36.18 \mathrm{a}$ & $57.71 \mathrm{a}$ & $0 \mathrm{~b}$ & $2.00 \mathrm{~b}$ & $4.11 \mathrm{c}$ & $100 \mathrm{a}$ \\
\hline CV \% & 48.37 & 23.19 & 92.01 & 63.19 & 33.69 & 12.48 \\
\hline
\end{tabular}

Means followed by the same letter comparing samples do not differ from each other by the $5 \%$ Tukey test.

The presence of full seeds with or without visualized embryos (Figures $2 \mathrm{~d}$ and $2 \mathrm{e}$ ) ranged from 6.11 to $92.03 \%$, according to the sample (Table 1).

Correlation between climatic factors and seed quality was observed (Table 2). There was a strong linear correlation between empty seeds and altitude, showing that the higher the altitude, the greater the number of empty seeds. The relationship between temperature and rainfall was inverse, that is, the lower the temperature and rainfall, the higher the number of empty seeds.

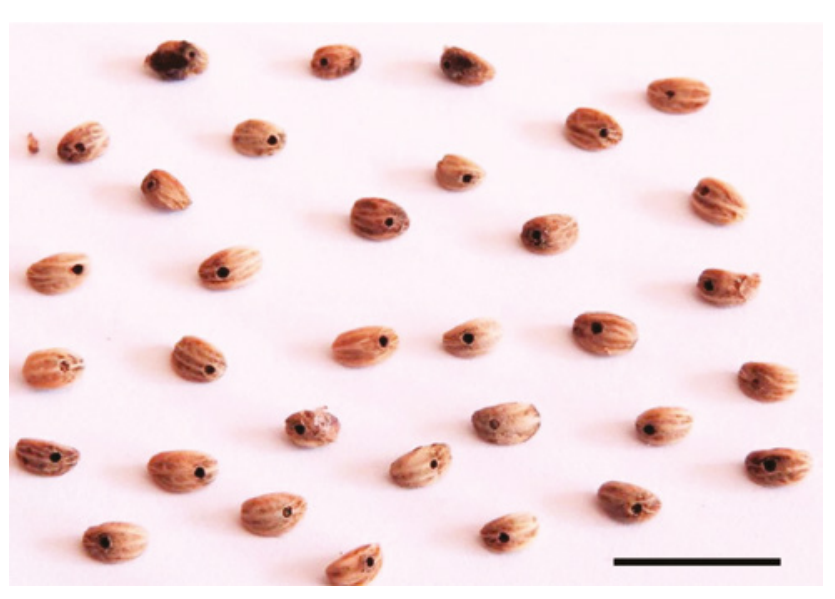

Figure 3. Ilex paraguariensis seeds with signs of herbivory. Scale bar: $1 \mathrm{~cm}$.

The correlation between temperature and empty seeds can be explained by pollination as it is entomophilous, and low temperatures may decrease insect visits. When evaluating pollination in I. paraguariensis, Pires et al. (2014) and Liebsch \& Mikich (2009) observed there was greater visitation of flower pollinators in the periods with higher temperatures during the day. I. paraguariensis flowering occurs in the warmer months after winter, with average temperatures above $13{ }^{\circ} \mathrm{C}$ (Pires et al., 2014).

Table 2. Pearson correlation between Ilex paraguariensis seeds classes and climatic variables.

\begin{tabular}{cccc} 
& Altitude & Temperature & Rainfall \\
\hline Empty & 0.81 & -0.84 & -0.74 \\
\hline Died & 0.63 & -0.59 & 0.46 \\
\hline Herbivory & 0.33 & -0.39 & 0.46 \\
\hline Full & -0.95 & 0.94 & 0.08 \\
\hline
\end{tabular}

Most of the seeds filled with visualized embryo were considered viable by the tetrazolium test (Table 1). Although viable, I. paraguariensis seeds are classified as dormant (Niklas, 1987; Heuser, 1990; Galíndez et al., 2018).

Based on the results, the low germination reported in I. paraguariensis seeds is not only related to dormancy, but also to factors that influence seed formation, considering the high number of empty/deteriorated seeds observed, in addition to the low temperature and higher altitude observed at the collection sites correlated with the high number of empty seeds.

\section{SUBMISSION STATUS}

Received: 19 Sept. 2017

Accepted: 3 Nov. 2019

Associate editor: Juliana Müller Freire

(1D) 0000-0002-4758-2533 


\section{CORRESPONDENCE TO}

\section{Anieli Cioato de Souza}

Universidade do Estado de Santa Catarina (Udesc), Av. Luís de Camões, 2.090, CEP 88520-000, Lages, SC, Brasil

e-mail: anielicioato@hotmail.com

\section{ACKNOWLEDGEMENTS}

The authors thank Fundação de Amparo à Pesquisa e Inovação do Estado de Santa Catarina (Fapesc) (2017TR639) for the financial support, Coordenação de Aperfeiçoamento de Pessoal de Nível Superior (Capes) for awarding doctoral scholarship to the first author, and Ph.D. Tiago Geog Pikart for insect identification.

\section{REFERENCES}

Arrieta S, Suárez F. Germination and seed bank depletion of holly (Ilex aquifolium L.) in four microhabitat types. Seed Science Research 2004; 14: 305-313. 10.1079/SSR2004180

Catapan MIS. Influência da temperatura, substrato e luz na germinação de sementes de Ilex paraguariensis St. Hil. [thesis]. Curitiba: Universidade Federal do Paraná, 1998.

Carvalho PER. Espécies arbóreas brasileiras. Colombo: Embrapa Florestas; 2003.

Climate Data. Dados climáticos para cidades mundiais [Internet]. 2014 [cited 2016 Sept. 9]. Available from: http://bit.ly/2EGIkV2

Cuquel FL, Carvalho MLM, Chama HMCP. Avaliação de métodos de estratificação para a quebra de dormência em sementes de erva-mate. Scientia agricola 1994; 51(3): 415-221. 10.1590/S010390161994000300006

Galíndez G, Ceccato D, Bubillo R, Lindow-López L, Malagrina G, Ortega-Baes P, Baskin CC. Three levels of simple morphophysiological dormancy in seeds of Ilex (Aquifoliaceae) species from Argentina. Seed Science Research 2018; 28(2): 1-9. 10.1017/S0960258518000132

Garcia D, Obeso JR, Martinez I. Rodent seed predation promotes differential recruitment among bird-dispersed trees in temperate secondary forests. Oecologia 2005; 144: 435-446. 10.1007/s00442005-0103-7

Heuser ED. Ilex paraguariensis St. Hill: endosperma e embrião durante a embriogênese tardia [thesis]. Porto Alegre: Universidade Federal do Rio Grande do Sul, 1990.

Liebsch D, Mikich BOS. Fenologia reprodutiva de espécies vegetais da Floresta Ombrófila Mista do Paraná, Brasil. Revista Brasileira de Botânica 2009; 32: 375-391. 10.1590/S0100-84042009000200016

Kollmorgen. Munsell soil color charts. Baltimore; 1975.

Niklas CO. Estudios Embriologicos y citologicos en la yerba mate Ilex paraguariensis (Aquifoliaceae). Instituto de Botánica del Nordeste 1987; 6: 45-56. 10.30972/bon.611504

Oliveira ME. Patologia de sementes. Palmas: Universidade Federal do Tocantins; 2013.

Oliveira SV, Waquil PB. Dinâmica de produção e comercialização da erva-mate no Rio Grande do Sul, Brasil. Ciência Rural 2015; 45 750-756. 10.1590/0103-8478cr20140276

Pires EZ, Stedille LIB, Machado S, Mantovani A, Bortoluzzi RLC. Biologia reprodutiva de erva-mate (Ilex paraguariensis A. St. Hil) em remanescente de Floresta Ombrófila Mista Altomontana. Revista de Ciências Agroveterinárias 2014; 13(2): 171-180.

Sousa VA, Daros TL, Sturion JA. Fenologia reprodutiva de erva-mate (Ilex paraguariensis St. Hil). Brasília, DF: Embrapa Florestas-CNPF, 2003.

Takagi E, Togashi K. Oviposition of the seed parasitoid wasp Macrodasyceras hirsutum (Hymenoptera: Torymidae) into seeds of nonhost tree Ilex latifolia. Journal of the Entomological Research Society 2013; 15(2): 17-20.

Zanon A. Circular técnica $n^{\circ}$ 16: produção de sementes de erva mate. Brasília, DF: Embrapa; 1988. 